\title{
The Effect of Industrial Heat Treatment on The Wettability and Dimensional Stability of Ash (Fraxinus excelsior) Wood
}

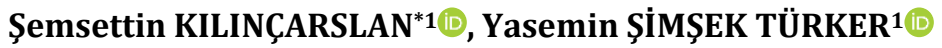 \\ ${ }^{1}$ Suleyman Demirel Univesity, Faculty of Engineering, Department of Civil Engineering, 32600, Isparta, Turkey
}

(Alınış / Received: 07.09.2020, Kabul / Accepted: 19.10.2021, Online Yayınlanma / Published Online: 25.12.2021)

\section{Keywords}

Heat treatment,

Ash,

Wettability,

Dimensional stability

\begin{abstract}
In this study is to examine the effect of industrial heat treatment application on the dimensional stability and dynamic wettability properties of ash (Fraxinus excelsior) wood. Ash samples that were heat treated for 120 minutes at 210 degrees according to the ThermoWood process were used. In this study, a total of 30 samples, including 15 heat treated samples with dimensions of 20x20x30 mm, and 15 unheat treated samples were cut and the dynamic wettability and dimensional stability properties were examined.

The results obtained in the study showed that the wettability property of the wood material decreased with the application of heat treatment. It has been determined that the dimensional stability is higher especially in tangential section compared to radial section. It was also found that there is a significant correlation between dynamic wettability property and dimensional stability.
\end{abstract}

\section{Endüstriyel Isıl İşlemin Dişbudak (Fraxinus excelsior) Odununun Boyutsal Stabilite ve Islanabilirliği Üzerine Etkisi}

Anahtar Kelimeler

Isıl işlem,

Dișbudak,

Islanabilirlik,

Boyutsal kararlılık

\begin{abstract}
Özet: Çalışmada, endüstriyel ısıl işlem uygulamasının dişbudak (Fraxinus excelsior) odununun boyutsal stabilite ve dinamik islatma özelliği üzerine etkisini incelemektir. ThermoWood prosesine göre 210 derece 120 dakika boyunca isıl işlem görmüş Dişbudak numuneleri kullanılmıştır. Çalışmada 20x20x30 mm boyutlarına sahip 15 adet Isıl ișlem görmüș numune 15 adet ısıl işlem görmemiș numune olmak üzere toplam 30 numune biçilmiş ve dinamik ıslatma özelliği ile boyutsal stabilite özellikleri incelenmiştir.

Çalışmada elde edilen bulgular, ısıl işlem uygulaması ile birlikte ağaç malzemenin ıslanabilme özelliğinin azaldığını göstermiştir. Özellikle radyal kesite nazaran teğet kesitte boyutsal kararlılı̆ı̆ın daha yüksek olduğu tespit edilmiştir. Ayrıca dinamik ıslatma özelliği ile boyutsal kararlılı arasında önemli bir korelasyon olduğu belirlenmiștir.
\end{abstract}

\section{Introduction}

Demand for sustainable construction materials is increasing in order to reduce energy consumption and $\mathrm{CO}_{2}$ emissions throughout the World [1-4]. Wood is one of the oldest building materials. Among the materials used in construction, only the source of the wood material can be renewed [5]. Wood is a material that is frequently used in building industry and it can be easily found $[2,6]$. For many years wood materials have been used in building sector but reinforced concrete structures have gained importance in time and the application areas of wood material has decreased. In recent years, the use of wood and wood composites has become popular again with the importance of cost [7-9]. There is a wide range of applications such as furniture, building, road works and water supply works [2]. Due to the easy processing and shaping of wood materials, it has expanded its usage area continuously. With the opportunities provided by today's technology, the usage area has diversified in time [10]. However, as it is an anisotropic material, it has some negative results due to its limited resistance and water supply. Due to the changes in the size of the water contact or in areas where high humidity is used for a long time is possible after some operations [11]. Recently, the most common method is to impregnate toxic chemicals on wood. However, the treatment of wood with toxic chemicals has a negative effect on both 
human health and the environment. Therefore, various heat treatment methods have been developed in order to process wood material without treatment with chemicals $[12,13]$.

Heat treatment methods applied for experimental and commercial purposes; Fin (ThermoWood) method, Plato method, Rectification method, Oil heat treatment methods [14]. The elasticity modulus, bending strength and compressive strength are important for the load-bearing structural elements. Dimensional stabilization is an important factor for wood materials used in damp environments such as sauna, bathroom and garden furniture [15]. Knowing the dimensional stability property of wood material is important in determining the place of use of this material.

Since hemicelluloses have the lowest molecular weight, they begin to degrade at higher temperatures in heat treatment. The degradation of hemicellulose leads to a decrease in the assembly of the $\mathrm{OH}$ bond and the 0-acetyl group [16, 17]. Pavlo and Niemz (2003)[18] found that heat treatment applied at high temperatures to the material obtained from spruce wood species caused darkening of color, increased dimensional stability but impaired mechanical properties [19]. Kocaefe et al. (2008) [16] examined the effect of heat treatment on the wettability of ash and maple samples. In their study, they determined the axial contact angles of maple and ash samples subjected to heat treatment at different temperatures. They found that the contact angle values were higher in the heat treated samples.

Petrissans et al. (2003) [20] treated with chemical and heat treatment spruce poplar, beech and pine wood in their study on the wettability of the material, heat treated materials have determined that a higher rate of hydrophobicity. Hakkou et al. (2005) [21] state that the change in wettability is a result of the plasticization of free water or lignin. Hill (2006) [12] stated that there is a decrease in hydrophilicity with an increase in the contact angle, so the rate of swelling and shrinkage of the material decreases with an increase in the contact angle values.

It is important both industrially and academically to know the changes in the technological properties of the trees of industrial importance after heat treatment application. Dimensional stability properties of wood material are one of the most important issues to be considered especially in materials used in outdoor weather conditions. Therefore, there are many studies on dimensional stability and wettability of wood material. In this study, heat treated (treatment) and unheat-treated (control) Ash (Fraxinus excelsior) woods were used for wettability, dimensional stability tests. The primary aim of this study is to examine the wettability and dimensional stability properties of heat treated materials obtained from different types of trees in tangential and radial sections. In addition, heat treated samples are compared with unheat treated samples to examine surface wettability, swelling-shrinking behaviour.

\section{Material and Methods}

\subsection{Preparation of Test Samples}

In this study, Ash (Fraxinus exelsior L.) woods, which are widely used in wood working and furniture industry, were used. The wood materials used were obtained from the Naswood plant operating in Dosemealti, Antalya (Nasreddin Forest Products). It has been ensured that this timber provided is perfect and that the fibers are smooth, without backing, without reaction wood, and has not suffered from fungal and insect damages. The lumber supplied was divided into two parts from the core, and one part was heat treated, while the remaining part remained as a control sample. The ash wood used in the study was subjected to heat treatment in Nasreddin Forest Products Factory according to "ThermoWood" process for 120 minutes at $210^{\circ} \mathrm{C}$ (This time refers to the temperature and time applied to the heat treatment in the second stage).

\subsection{Measurement of Contact Angle}

Firstly, timber (control and treatment) was cut with a motorized saw blade in dimensions of $20 \times 20 \times 30 \mathrm{~mm}$ (thickness $\mathrm{x}$ width $\mathrm{x}$ length) to make the surface wettability test. A total of 30 samples, 15 from control samples and 15 from treatment samples, were studied.

After the samples were taken, the surfaces of the samples were sanded to obtain surface smoothness. The samples were stored at $20 \pm 5{ }^{\circ} \mathrm{C}$ at $60 \pm 5 \%$ relative humidity until they reached equilibrium humidity. In this study, contact angle values were determined to determine the surface wettability of ash samples. A schematic view of the system established to indicate the surface contact angles of the samples is given in Figure 1.
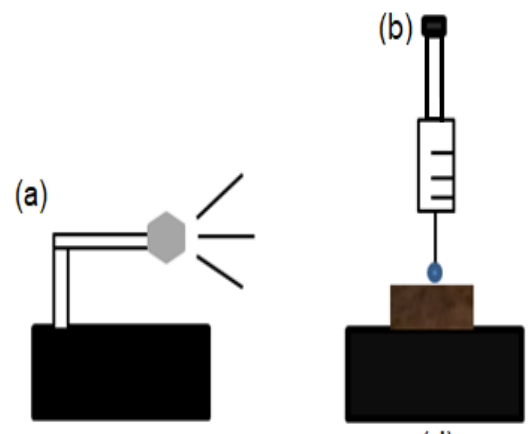

(d)

Figure 1. Schematic view of contact angle measuring device a: Light and control center, b:Micro syringe, c: Camera, d: Sample placement table 
The distilled water was drilled down to $5 \mu$ with the help of a syringe. With a syringe, a drop of water was dropped on the surface of the material and an image was taken every 5 seconds. Therefore, 7 images were taken for 30 seconds for one sample [16, 22]. The contact angle values were determined on the images taken with the image analysis program "Image J". It is shown in Figure 2 that the drops drawn for 30 seconds every 5 seconds are seen on the control and treatment samples of the ash wood.

The contact angle values measured by the image analysis program are measured according to results of Štrbová et al. (2013) [23] study and Cengiz, 2010 [24](Figure 3).

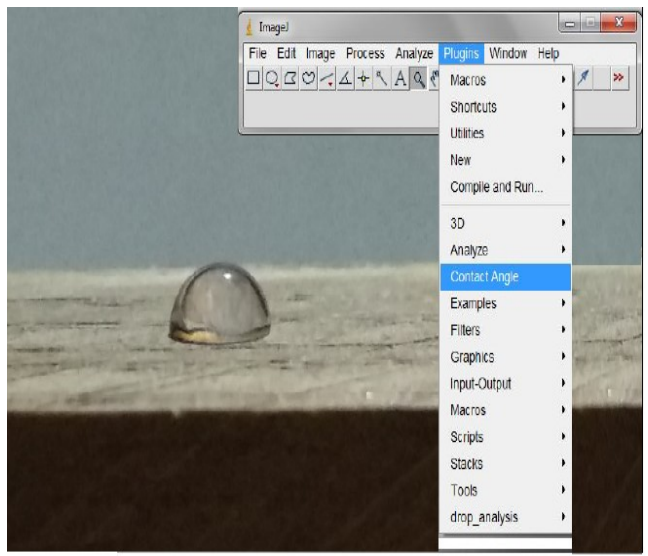

Figure 3. Determination of contact angle in image analysis program

Comparison tables with the contact angle values obtained using the image analysis program (Image J) were created.

\subsection{Measurement of Swelling and Shrinkage}

In this study, dimensional change was examined in terms of shrinkage and swelling. In this study, TS 4083 [25] was used to determine the shrinkage value and TS 4084 [26] standard was used to determine the swelling value. The weight of the test pieces was immersed in distilled water at $20 \pm 5^{\circ} \mathrm{C}$ in a container until the weight became unchanged and then measurements were made and recorded. The test pieces were dried to about $12-15 \%$ humidity in normal room conditions. Humidity values of the samples were measured and checked with Gann brand moisture meter. The test pieces were dried in the drying cabinet until they reached a constant weight of $103 \pm 2^{\circ} \mathrm{C}$. Measurements were taken when the samples became fully dry.

The following Equation was used in the calculation of the shrinkage quantities [25];

$$
\beta=\frac{L_{2-} L_{1}}{L_{2}} \times 100(\%)
$$

$\mathrm{L}_{2}$, dimensions of the test piece which has a moisture level on the fiber saturation point in radial (R), tangential (T) and longitudinal (L) directions ( $\mathrm{mm}$ ); $\mathrm{L}_{1}$, the dimensions of the test piece in $\mathrm{R}, \mathrm{T}$ and $\mathrm{L}$ directions after drying ( $\mathrm{mm})$.

The $\mathrm{T}, \mathrm{R}$ and $\mathrm{L}$ direction measurements were used to determine the percentage of the shrinkage in the tangent $\left(\beta_{\mathrm{t}}\right)$, radial $\left(\beta_{\mathrm{r}}\right)$, and the longitudinal direction $\left(\beta_{1}\right)$. The volumetric shrinkage $\left(\beta_{\mathrm{v}}\right)$ was calculated by the following Equation [26].

$$
\beta_{v=} \beta_{t+} \beta_{r+} \beta_{l}
$$

The test pieces were dried in the drying cabinet until they reached constant dimensions at $103 \pm 2{ }^{\circ} \mathrm{C}$. Then, the test pieces were immersed in distilled water in a container until the dimensions of the test pieces remained unchanged. After the samples were removed from the water, the measurements were taken and the following Equation was used to calculate the amount of swelling $(\alpha)$.

$$
\alpha=\frac{L_{2-} L_{1}}{L_{2}} \times 100(\%)
$$

Where; L2, dimensions of the test piece which has a moisture level on the fiber saturation point in $\mathrm{R}, \mathrm{T}$ and $\mathrm{L}$ directions ( $\mathrm{mm}$ ); $\mathrm{L}_{1}$, the dimensions of the test piece in $\mathrm{R}, \mathrm{T}$ and $\mathrm{L}$ directions after drying ( $\mathrm{mm}$ ).
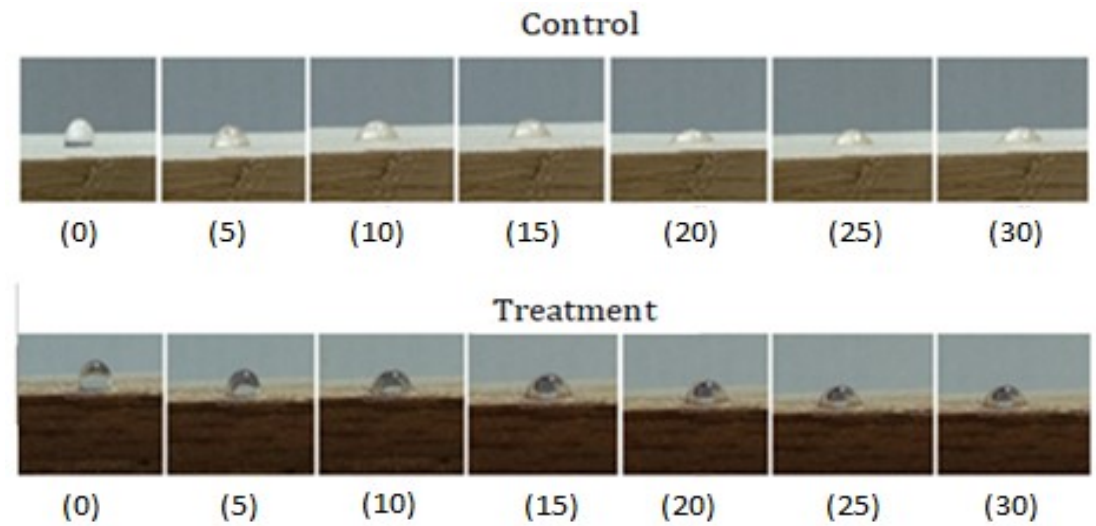

Figure 2. Water drop on ash wood (control and treatment) samples (0-30 seconds) 
The $\mathrm{T}, \mathrm{R}$ and $\mathrm{L}$ direction measurements were used to determine the percentage of the swelling in the tangent $\left(\alpha_{\mathrm{t}}\right)$, radial $\left(\alpha_{\mathrm{r}}\right)$, and the longitudinal direction $\left(\alpha_{1}\right)$. The volumetric swelling $\left(\alpha_{V}\right)$ was calculated by the following Equation [26].

$$
\alpha_{v=} \alpha_{t+} \alpha_{r+} \alpha_{l}
$$

After determining the contact angle, swelling and shrinkage percentages, graphs were generated and values were met for both contact angle and swellingshrinkage values. The data were entered into the SPSS analysis program and analyzed.

\section{Results}

The tangential and radial direction contact angle values of the Ash (Control-Treatment) test samples are given in Figure 4.

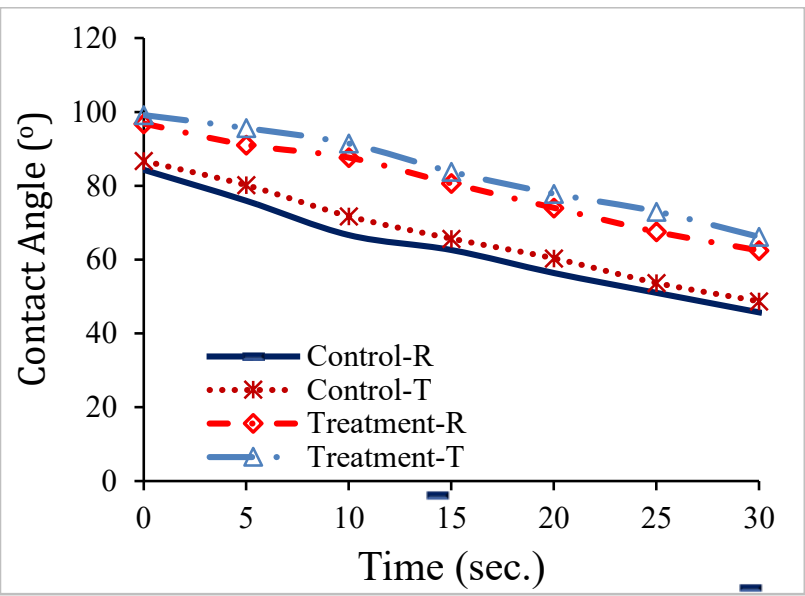

Figure 4. Contact angle values of Ash samples (0-5-10-1520-25-30 sc.)

Table 1 shows ash wood contact angle measurement results.

When the measurements taken for thirty seconds were evaluated, it was determined that the contact angle value decrease rate of the control samples was 39.53 in the contact angle values are approximately 2-6 degrees lower than tangential surface contact angle values. According to the T-test results, the contact angle values of the heat treated samples have increased significantly compared to the control sample $(\mathrm{p}<0.05)$.

Hill (2006) [12] stated that there is a decrease in hydrophilicity with an increase in the contact angle, and thus the rate of expansion and contraction of the material with an increase in contact angle values. Since the surfaces of the heat treated wood are less polar, they are waterproof and thus have less wettability than wood without heat treatment. After determination of dynamic wettability properties, radial, tangential and volumetric, swelling and shrinkage amounts of wood species were determined. The results of the swelling and shrinkage of the ash samples are given in Table 2, Figure 5 and Figure 6.

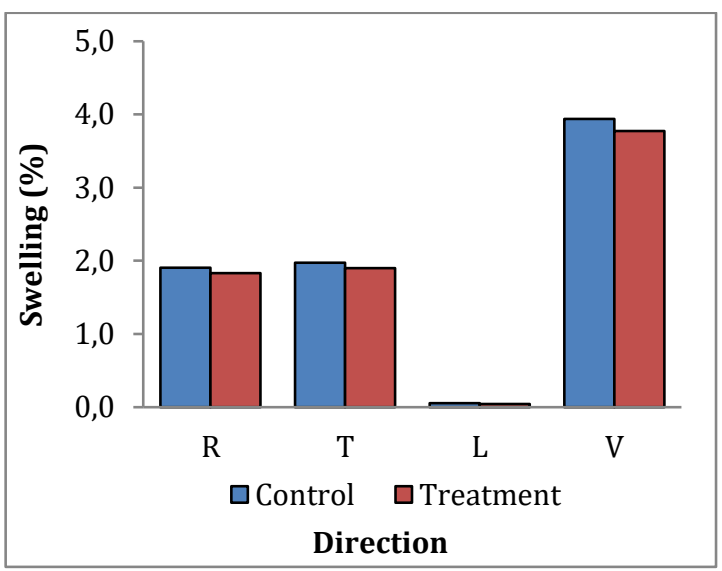

Figure 5. Radial, tangential, longitudinal and volumetric swelling graph

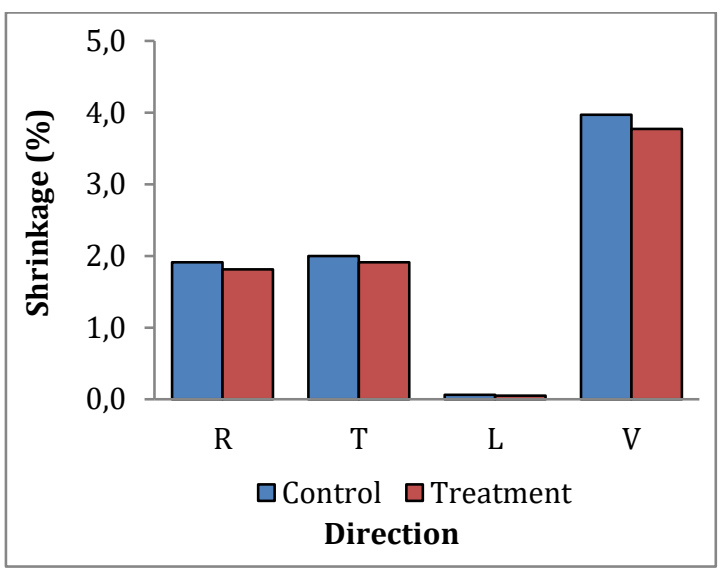

Figure 6. Radial, tangential, longitudinal and volumetric shrinkage graph

In Table 2, it is seen that the volumetric swelling percentage is $3.94 \%$, the volumetric shrinkage percentage is $3.97 \%$ in the control samples, the volumetric swelling percentage is $3.77 \%$ and the volumetric shrinkage percentage is $3.77 \%$ in treatment samples.

When the contraction and swelling amounts are examined, it is seen that the shrinkage and swelling values of the heat treated samples are significantly lower $(\mathrm{p}<0.05)$.

In particular, when the percentages of swelling and shrinkage in the $\mathrm{R}$ and $\mathrm{T}$ directions are examined, the surface swelling and shrinkage values of the control samples are respectively $1.91 \%-1.91 \%$ in the radial direction and $1.98 \%-2.00 \%$ in the tangential direction, these values of the process samples are respectively $1.83 \%-1.81 \%$ in the radial direction and $1.90 \%-1.91 \%$ in the tangential direction. It is seen from these data that the percentage of swelling and shrinkage of radial surface is lower than tangential surface $(p<0,05)$. 
Table 1. Ash wood contact angle measurement results

\begin{tabular}{|c|c|c|c|c|c|c|c|c|c|c|c|c|c|c|c|}
\hline \multicolumn{16}{|c|}{ Mean (sc.) } \\
\hline & $\mathbf{N}$ & \multicolumn{2}{|c|}{0} & \multicolumn{2}{|c|}{5} & \multicolumn{2}{|c|}{10} & \multicolumn{2}{|c|}{15} & \multicolumn{2}{|c|}{20} & \multicolumn{2}{|c|}{25} & \multicolumn{2}{|c|}{30} \\
\hline \multirow{3}{*}{ UT (R) } & \multirow{3}{*}{15} & \multicolumn{2}{|c|}{84,30} & \multicolumn{2}{|c|}{75,91} & \multicolumn{2}{|c|}{66,62} & \multicolumn{2}{|c|}{62,58} & \multicolumn{2}{|c|}{56,35} & \multicolumn{2}{|c|}{50,98} & \multicolumn{2}{|c|}{45,70} \\
\hline & & Min & Max & Min & Max & Min & Max & Min & Max & Min & Max & Min & Max & Min & Max \\
\hline & & 78,15 & 94,24 & 69,75 & 85,75 & 54,40 & 74,70 & 51,94 & 67,16 & 40,50 & 62,66 & 38,16 & 58,69 & 35,40 & 52,20 \\
\hline \multirow{3}{*}{ UT (T) } & \multirow{3}{*}{15} & \multicolumn{2}{|c|}{86,71} & \multicolumn{2}{|c|}{80,15} & \multicolumn{2}{|c|}{71,73} & \multicolumn{2}{|c|}{65,67} & \multicolumn{2}{|c|}{60,32} & 53 & & & 68 \\
\hline & & Min & Max & Min & Max & Min & Max & Min & Max & Min & Max & Min & Max & Min & Max \\
\hline & & 81,75 & 96,48 & 73,67 & 89,37 & 60,73 & 77,37 & 53,65 & 69,79 & 50,97 & 65,85 & 42,98 & 59,37 & 38,14 & 55,40 \\
\hline & & & 84 & & & & & & 61 & 74 & & 67 & & & 46 \\
\hline HT(R) & 15 & Min & Max & Min & Max & Min & Max & Min & Max & Min & Max & Min & Max & Min & Max \\
\hline & & 90,48 & 102,19 & 81,37 & 97,38 & 80,27 & 92,94 & 70,26 & 89,36 & 67,48 & 82,20 & 61,39 & 75,44 & 53,79 & 69,75 \\
\hline & & & 13 & & & & & & 80 & 77 & & 73 & & & 15 \\
\hline HT (T) & 15 & Min & Max & Min & Max & Min & Max & Min & Max & Min & Max & Min & Max & Min & Max \\
\hline & & 92,15 & 105,18 & 90,95 & 102,37 & 88,37 & 95,18 & 74,86 & 90,64 & 61,38 & 84,46 & 59,63 & 79,37 & 59,25 & 74,79 \\
\hline & & & & & & & indard & iati & & & & & & & \\
\hline UT (R) & 15 & & 14 & & & & & & 34 & & & & & & \\
\hline UT (T) & 15 & & 18 & & & & & & 40 & & & & & & \\
\hline HT(R) & 15 & & 81 & & & & & & 98 & & & & & & \\
\hline HT (T) & 15 & & 84 & & & & & & 33 & & & & & & \\
\hline & & & & & & & $\tan d$ & rror & & & & & & & \\
\hline UT (R) & 15 & & 32 & & & & & & 12 & & & & & & \\
\hline UT (T) & 15 & & 33 & & & & & & 13 & & & & & & \\
\hline HT(R) & 15 & & 98 & & & & & & 54 & & & & & & \\
\hline HT (T) & 15 & & 99 & & & & & & 37 & & & & & & \\
\hline & & & & & & & Su & & & & & & & & \\
\hline UT (R) & 15 & 126 & 4,45 & & 3,61 & & & & 65 & 845 & & 76 & & & \\
\hline UT (T) & 15 & 130 & 0,65 & & 2,27 & & 95 & & 02 & 904 & & 80 & & & \\
\hline HT(R) & 15 & 145 & 2,55 & & 5,80 & & 34 & & 9,11 & 111 &, 12 & 101 & 57 & & 93 \\
\hline HT (T) & 15 & 148 & 6,88 & & 3,93 & & 43 & & 6,98 & 116 & 7,54 & 109 & 08 & & 26 \\
\hline & & & & & & & ficient & Varia & & & & & & & \\
\hline UT (R) & 15 & & 06 & & & & & & 7 & & & & & & \\
\hline UT (T) & 15 & & 06 & & & & & & 7 & & & 0 , & & & \\
\hline HT(R) & 15 & & 04 & & & & & & 7 & & & & & & \\
\hline HT (T) & 15 & & 04 & & & & & & 66 & & & & & & \\
\hline
\end{tabular}

N: Number of Sample, UT: Unheat-treated, HT: Heat-treated, R: Radial direction, T: Tangential direction, Min: Minimum, Max: Maximum

Table 2. Results of the swelling and shrinkage test of the Ash samples

\begin{tabular}{|c|c|c|c|c|c|c|c|c|c|c|c|c|c|c|}
\hline \multirow[b]{2}{*}{ Direct. } & \multirow[b]{2}{*}{ Treatment } & \multirow[b]{2}{*}{$\mathbf{N}$} & \multicolumn{6}{|c|}{ Swelling } & \multicolumn{4}{|c|}{ Shrinkage } & \multirow[b]{2}{*}{ Max } & \multirow[b]{2}{*}{ SE } \\
\hline & & & Mean (\%) & SD & CV & Min & Max & SE & Mean (\%) & SD & $\mathrm{CV}$ & Min & & \\
\hline \multirow{2}{*}{$\mathbf{R}$} & UT & 15 & 1,91 & 0,06 & 0,03 & 1,80 & 1,99 & 0,01 & 1,91 & 0,06 & 0,03 & $\begin{array}{c}1,8 \\
2 \\
\end{array}$ & 2,00 & 0,01 \\
\hline & HT & 15 & 1,83 & 0,07 & 0,04 & 1,71 & 1,96 & 0,01 & 1,81 & 0,06 & 0,03 & 1,70 & 1,91 & 0,01 \\
\hline \multirow{2}{*}{$\mathbf{T}$} & UT & 15 & 1,98 & 0,06 & 0,03 & 1,90 & 2,07 & 0,01 & 2,00 & 0,06 & 0,03 & 1,91 & 2,16 & 0,01 \\
\hline & HT & 15 & 1,90 & 0,06 & 0,03 & 1,83 & 1,99 & 0,01 & 1,91 & 0,06 & 0,03 & 1,83 & 2,00 & 0,01 \\
\hline \multirow{2}{*}{$\mathbf{L}$} & UT & 15 & 0,06 & 0,02 & 0,32 & 0,037 & 0,087 & 0,004 & 0,06 & 0,02 & 0,27 & 0,036 & 0,088 & 0,004 \\
\hline & HT & 15 & 0,04 & 0,01 & 0,30 & 0,021 & 0,071 & 0,003 & 0,05 & 0,02 & 0,34 & 0,021 & 0,724 & 0,004 \\
\hline \multirow{2}{*}{ V } & UT & 15 & 3,94 & 0,10 & 0,02 & 3,807 & 4,107 & 0,025 & 3,97 & 0,11 & 0,03 & 3,817 & 4,170 & 0,028 \\
\hline & HT & 15 & 3,77 & 0,11 & 0,03 & 3,568 & 3,988 & 0,028 & 3,77 & 0,11 & 0,03 & 3,596 & 3,964 & 0,027 \\
\hline
\end{tabular}

SD: Standard Deviation, SE: Standard Error, CV: Coefficient of Variation, N: Number of Samples, R: Radial, T: Tangential, L: Longitudinal, V: Volumetric, Min: Minimum, Max: Maximum 


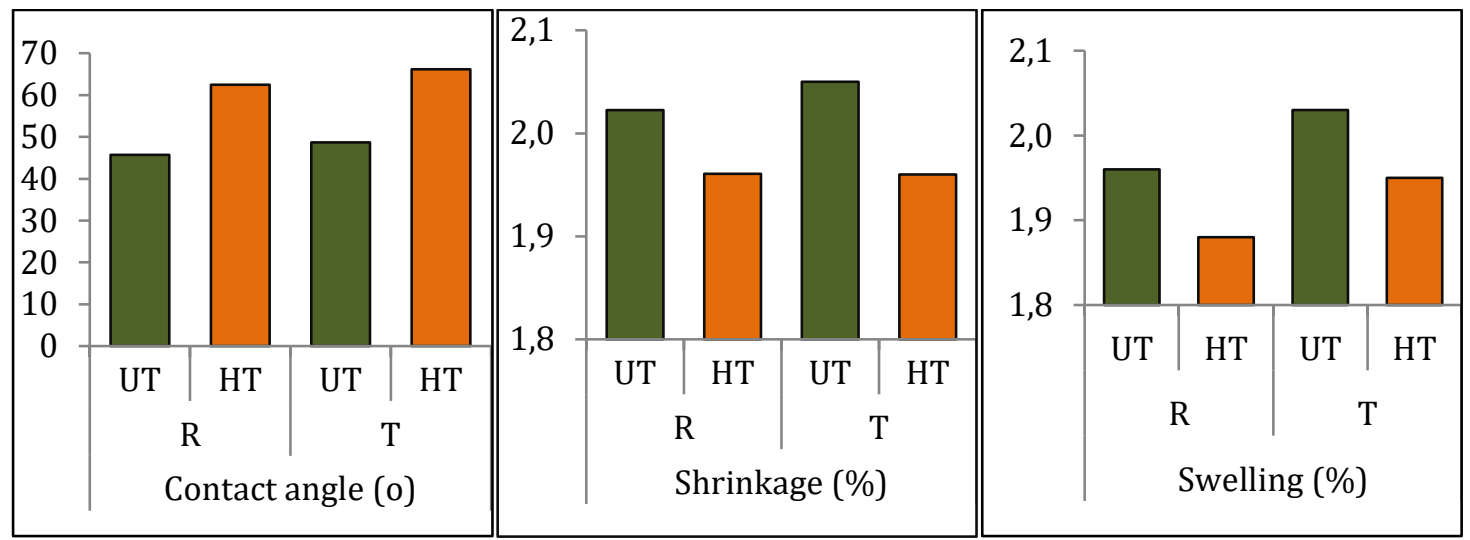

Figure 7. Contact angle, swelling and shrinkage values in radial and tangential directions (R: Radial, T:Tangential)

Dimensional stability properties of wood material are one of the most important issues to be considered especially in materials used in outdoor weather conditions. Therefore, there are many studies on dimensional stability and wettability of wood material. The findings obtained from these studies show that the dimensional stability of wood material varies depending on many factors such as material type, heat treatment application conditions, heat treatment temperature and duration. In most studies on this subject, it has been stated that the dimensional stability of heat treated wood has increased and thus the swelling and shrinkage percentages of the wood material have decreased [27-39, 22].

Heat treatment of wood significantly reduces its water adsorption $(\mathrm{p}<0,05)$. Decrease in accessibility of free hydroxyl groups as a result of heat treatment application is undoubtedly obvious [12, 40]. In this study, especially in radial and tangential directions, when the contact angle, swelling and shrinkage values were compared, the contact angle values of the heat treated (HT) samples were higher than the unheat treated (UT) samples and the contraction and expansion values were lower (Figure 7).

In this study, when the contact angle, swelling and shrinkage values were compared, it was determined that there was a negative correlation between the contact angle values and swelling and shrinkage values, but there was a positive correlation between swelling and shrinkage values. In other words, with the increase in contact angle values, it was concluded that the amount of swelling and shrinkage decreased according to the statistical data results.

\section{Discussion and Conclusion}

When the contact angle values of the heat treated and non-heat treated samples were examined, it was determined that the contact angle values increased with the heat treatment application.

With the increase in the contact angle, there is a decrease in hydrophilicity and thus the dimensional stability of the material increases with the increase in contact angle values.

Therefore, according to the results of the dynamic wetting tests, it is seen that the heat treatment application reduces the wettability of the material. It has been found that the contact angle measurement values made in the tangential and radial directions give close results, but the contact angle values in the radial direction are lower than the contact angle values in the tangential direction. This result shows that the wettability in the tangential direction is lower than the radial direction.

When the percentages of swelling and shrinkage were examined, it was determined that with the application of heat treatment, the percentage of swelling and shrinkage of wood material decreased and therefore dimensional stability property increased.

In conclusion, the contact angle values of the heat treated materials and the percentages of swelling and shrinkage gave similar results. As a result of both experiments, it is seen that heat treatment reduces the wettability of wood material. The wettability of wood materials can be shown as an indicator of dimensional stability. For this reason, it is possible to get a preliminary idea about this feature with the contact angle method instead of long-term and laborious studies to obtain information about the dimensional stability of wooden materials.

\section{Acknowledgements}

This study has been prepared within the scope of the thematic area of "Sustainable Building Materials and Technologies" with SDK BAP project with FDK-20196950 project code and YÖK 100/2000 doctoral program. The authors thank the SDU BAP unit, YÖK and YÖK 100/2000 program staff. The heat treated wood materials used in the study were obtained from Nasreddin Forest Products (Naswood). The authors would like to thank Nasreddin Forest Products Company officials. 


\section{Declaration of Ethical Code}

In this study, we undertake that all the rules required to be followed within the scope of the "Higher Education Institutions Scientific Research and Publication Ethics Directive" are complied with, and that none of the actions stated under the heading "Actions Against Scientific Research and Publication Ethics" are not carried out.

\section{References}

[1] Özbalta, T., Çakmanus, İ. 2008. Sustainability in Buildings: Approaches to lifetime cost. Doğa Sectoral Publications, İstanbul.

[2] Korkut, S., Kocaefe, D. 2009. Effect of heat treatment on wood properties Düzce University Journal of Forestry, 5(2), 11-34.

[3] Mardiana, A., Riffat, S. B. 2015. Building energy consumption and carbon dioxide emissions: threat to climate change. Journal of Earth Science \& Climatic Change, (S3), 1.

[4] Doğan, M., Seçme, D., Akten, M. 2018. Environmentally Friendly Buildings and Green Building Certificate Systems. Akademia Journal of Interdisciplinary Scientific Researches, 4(1), 19-27.

[5] Gürer, C., Akbulut, H., Kürklü, G. 2004. Recycling in the construction industry and re-evaluation of different building materials as a source of raw materials. V. Industrial Raw Materials Symposium, 28-36.

[6] Ramage, M. H., Burridge, H., Busse-Wicher, M., Fereday, G., Reynolds, T., Shah, D. U., Allwood, J.2017. The wood from the trees: The use of timber in construction. Renewable and Sustainable Energy Reviews, 68, 333-359.

[7] Karade, S. R. 2010. Cement-bonded composites from lignocellulosic wastes. Construction and building materials, 24(8), 1323-1330.

[8] Franek, J., Kollár, M., Makovíny, I. 2011. Microwave Electromagnetic Filed and Temperature Distribution in a Multilayered Wood-Cement Board. Journal of Electrical Engineering, 62(1), 25-30.

[9] Aras, U., Kalaycıoğlu, H. 2016. Wood Based Composites And Application Areas. International Refereed Journal of Engineering And Sciences, Sayl: 6, 120-136.Doi: 10.17366/UHMFD.2016616664.

[10] Akkılıç, H., Kaymakcı, A. Ünsal, Ö. 2014. Potential of thermally treated wood as external cladding, 7. National Roof \& Facade Symposium, 3-4.

[11] Efe, F. T., Bal, B. C. 2016. Changes in Hardness Values of High Temperature Heat Treated Red
Pine (Pinus brutia Ten.) Wood. AKÜ FEMÜBİD, 16, 79-86.

[12] Hill, CAS. 2006. Wood Modification: Chemical, Thermal and Other Processes, Wiley Series in Renewable Resources, John Wiley \& Sons Inc., 260 pages, Chichester, UK. ISBN: 978-0-47002172-9.

[13] Garcia, R. A., de Carvalho, A. M., de Figueiredo Latorraca, J. V., de Matos, J. L. M., Santos, W. A., de Medeiros Silva, R. F. 2012. Nondestructive evaluation of heat-treated Eucalyptus grandis Hill ex Maiden wood using stress wave method. Wood Science and Technology, 46(1-3), 41-52.

[14] Rapp, A.O. (Ed.)., 2001. Review of heat treatment of wood. In: Proceedings of COST E22 Environmental optimisation of wood protection. Antibes, France, pp.6.

[15] Esen, R., Özcan, C. 2012. Effects of heat treatment on adhesion resistance of oak (Quercus petraea L.) wood material. Turkish Journal of Forestry, 13(2), 150-154.

[16] Kocaefe, D., Poncsak, S., Doré, G., Younsi, R. 2008. Effect of heat treatment on the wettability of white ash and soft maple by water. Holz als rohund werkstoff, 66(5), 355-361.

[17] Homan, W., Tjeerdsma, B., Beckers, E., Joressen, A. 2000. Structural and Other Properties of Modified Wood. Congress WCTE, Whistler, Canada 3.5.1-1-3.5.1.-8.

[18] Pavlo, B., Niemz, P. 2003. Effect of Temperature on Color and Strength of Spruce Wood. Holzforschung 57:539-546.

[19] Duchez, L., Herri, J.M., Guyonnet, R. 2001. Modelisation d'un Four de ' Retification du Bois. In: Proceedings of $8 \mathrm{i}^{\prime}$ eme Congr ' es franco- ' phone en Genie des Proc ' ed' es, Nancy, 17 au 19 Octobre 2001 ' (Groupe ENSIC 2001), pp 6168.

[20] Petrissans, M., Gerardin, P., El Bakali, I., Serraj, M. 2003. Wettability of Heat-Treated Wood. Holzforschung 57, 301-307.

[21] Hakkou, M., Petrissans, M., Zoulalian, A., Gerardin, P. 2005. Investigation of Wood Wettability Changes During Heat Treatment on the Basis of Chemical Analysis. Polym Degrad Stabil 89, 1-5.

[22] Kılınçarslan, Ş., Şimşek Türker, Y. 2019. Determination of Contact Angle Values of Heattreated Spruce (Picea abies) Wood with Image Analysis Program. Biomed J Sci \& Tech Res 18(4), DOI: 10.26717/BJSTR.2019.18.003183.

[23] Štrbová, M., Wesserle, F., Kúdela, J. 2013. Contact Angle Measurement on Wood by Drop Shape Analysis. In: Science for Sustainability. Györ Sopron, University of West Hungary, p. 16-22. 
[24] Cengiz, 0. 2010. Contact Angle Measurement Device Design. University of İstanbul Graduate School of Natural and Applied Sciences, Mechanical Engineering Department, Master's Thesis, 83s.

[25] TS 4083, Determination of radial and tangential shrinkage in wood, TSE, Ankara.

[26] TS 4084, Determination of radial and tangential swelling in wood, TSE, Ankara.

[27] Altınok, M., Perçin, O., \& Doruk, Ş. 2010. Investigation of The Effect Of Heat Treatment (Thermo-Process) on The Technological Properties of Wood Materials. Unıversty of Dumlupinar, Graduate School of Natural and Applied Sciences, (023), 71-84.

[28] Bal, B. C., Bektaş, İ. 2018. Determination of density relation with some physical properties in beech and poplar wood. Furniture and Wood Materials Research Journal, 1(1), 1-10.

[29] Sernek, M 2002. Comparative analysis of inactivated wood surfaces, Doctoral Dissertation, Virginia Polytechnic Institute and State University, 179 pages.

[30] Hillis, W.E., 1984. High temperature and chemical effects on wood stability Part 1: general considerations. Wood Sci. Technol 18(4), 281-293.

[31] Kim, G.H., Yun, K.E., Kim, J.J., 1998. Effect of heat treatment on the decay resistance and bending properties of radiata pine sapwood. Material und Organismen, 32 (2), 101-108.

[32] Viitaniemi, P., 1997. ThermoWood - Modifi ed Wood for Improved Performance in: Proceedings of the 4th Eurowood Symposium Wood - The Ecological Material, Stockholm, Sweden, Trätek Rapport No. P9709084, pp. 6769.

[33] Yıldız, S., 2002. Physical, mechanical and chemical properties of East beech and East spruce wood with heat treatment. K.T.Ü., Doctoral Thesis, 245s, Trabzon.
[34] Kamdem D.P., Pizzi A., Jermannaud A. 2002. Durability of heat-treated wood. Holz als RohundWerkstoff 60: 1-6.

[35] Bekhta, P. Niemz, P., 2003. Effect of high temperature on the change in color, dimensional stability and mechanical properties of spruce wood. Holzforschung 57(5), 539-546

[36] Ünsal, O., Ayrılmış, N., 2005. Variations in compression strength and surface roughness of heat-treated Turkish River Red Gum (Eucalyptus camaldulensis) wood. Journal of Wood Science, 51, 405-409.

[37] Akyıldız, M.H. Ateş, S., 2008. Effect of heat treatment on equilibrium moisture content (EMC) of some wood species in Turkey. Research Journal of Agriculture and Biological Sciences, 4 (6), 660-665.

[38] Aydemir, D. Gunduz, G. Altuntas, E. Ertas, M. Sahin, H.T. Alma, M.H., 2011. Investigating changes in the chemical constituents and dimensionalstability of heattreated hornbeam and Uludag fi r wood, BioResources 6(2), 13081321.

[39] Sahin Kol, H., 2010. Characteristics of heattreated Turkish pine and fir wood after ThermoWood processing. J. Environ. Biol. 31(6), 1007-1011.

[40] Karlsson, O. Sidorava, E. Moren, T. 2011. Infl uence of heat transferring media on durability of thermally modifi ed wood. BioResources 6(1), 356-372.

[41] Poncsac, S., Kocaefe, D., Younsi, R. 2011. Improvement of the heat treatment of jack pine (Pinus banksiana) using ThermoWood technology. Eur. J. Wood Prod. 69(2), 281-286.

[42] Boonstra, M.J. 2008. A two-stage thermal modification of wood. Ph.D. dissertation in cosupervision Ghent University and Université Henry Poincaré - Nancy 1, 297 p. ISBN 978-905989-210-1. 